\title{
Unsaleable Grocery Products, their Residual Value and Instore Logistics
}

(published in the International Journal of Physical Distribution and Logistics Management in 2015)

\section{Christina Holweg}

Institute for Retailing and Marketing, Vienna University of Economics and Business, 1020 Vienna, Austria;

Christoph Teller (corresponding author, c.teller@ surrey.ac.uk)

Department of Marketing and Retail Management, University of Surrey, GU2 7HX Guildford, United Kingdom;

\section{Herbert Kotzab}

Institute for Logistics and Supply Chain Management, University of Bremen, 2000 Bremen, Germany; 


\title{
Unsaleable Grocery Products, their Residual Value and Instore Logistics
}

\begin{abstract}
Purpose: The aims of this paper are (1) to explore the complexities of regularly implemented as well as irregularly occurring - sometimes improvised - instore logistics processes related to products which are declared unsaleable and (2) to identify the challenges and opportunities in managing instore logistics processes related to unsaleable products in grocery stores.

Methodology: We apply an embedded case study approach. Within each case, i.e. dominant store format, we investigate the instore logistics processes of 32 retail and wholesale stores and focus further on those processes related to products declared unsaleable. The case study research methodology comprises in-depth interviews with store and category managers, pointof-sale observations and secondary data research.
\end{abstract}

Findings: We identified four different specific instore logistics processes depending on the residual product value of unsaleable products. The analysis of these processes suggests that establishing more efficient return, disposal, recycling and, most importantly, redistribution processes leads to various benefits such as cost savings, more effective and efficient operations, better use of resources and waste reduction, while at the same time supporting charitable institutions and people in need.

Contribution: The contribution of this research is (1) to provide a better understanding of different ways of seeing and handling unsaleable products and (2) to reveal the significant importance of focusing on instore logistics beyond the point of sale with respect to the economic, ecological and social benefits to retailers, wholesalers and their stakeholder groups.

Keywords: instore logistics, retail logistics, case study research, food waste; 


\section{Introduction}

Retailing is an important economic sector. The current "Global Powers of Retailing Top 250" produced by Deloitte (2014) shows that the aggregate retail revenue of the 250 largest retailers exceeds USD 4.2 trillion. However, looking at the net profit margin of the largest ten retailers, we can see a range of between 0.2 and $6.1 \%$. One reason for the variation is the execution of supply chain management focusing on four areas: range of products, pricing, stocking and store execution (Fisher, 2009). Store execution more specifically includes front-office as well as back-office processes that can be seen as instore-related sales and logistics processes (Kotzab and Teller, 2005; Reiner et al., 2013).

When planning their product range, retailers decide which products to offer in each store and at each point in time. This leads to inventory management decisions whereby store managers determine the replenishment quantities as well as the inventory quantities that are directly put on the shelves. As Fisher (2009) shows, incorrect inventory management decisions in the department store sector have led to dramatic markdowns. This is the starting point for this paper, which provides deeper insight into what happens to products if there is not sufficient demand for them or they do not meet shoppers' expectations. In other words, it addresses what happens to products that become unsaleable at the point of sale. The answer to this question contains a strong logistics component since the location, quantity, quality and value of the products have to change when they become unsaleable - even if they are simply discarded. Evidently the devil is in the detail because "unsaleable" does not necessarily mean "inedible" and "to be disposed of".

What is seen as unsaleable by a retailer or wholesaler is often still consumable and usable from a consumer's perspective as long as basic quality and safety requirements are met (Papargyropoulou et al., 2014). Food products in particular are affected by the problem of 
unsaleability due to the high expectations regarding the logistics service level in stores, and their limited shelf life.

Consider the example of carrots that do not have a straight shape, apples that are slightly blemished, packages of meat that have passed the display by date, tins of beans that have dents, new varieties of yoghurt that do not sell and slow-moving rye bread that is sitting in the back room of a store. These products usually have two things in common: they are still edible, and at the end of their shelf life they are discarded. From a retailing and wholesale point of view this phenomenon, in relation to cost, is also known as shrinkage, i.e. missing inventory due to customer or employee theft, or administrative or any other issues related to logistics or store operation processes (e.g., Avery et al., 2012, Rekik and Sahin, 2012); from a logistics and supply chain management point of view, unsaleable grocery products turn into food waste sometimes also referred to as food loss - which represents an inefficient use of resources, and from an ethical point of view it represents a lost opportunity to provide consumers with nutrition.

In full appreciation of the fact that subject areas such as waste management (Mena et al., 2014) and reverse logistics (Hall et al., 2013) deal with aspects of the unsaleability of products indirectly, to our best knowledge there is no research that focuses on the topic of instore logistics relating to unsaleable products. In our paper, we will show that instore logistics processes for unsaleable products are capable of generating value for different stakeholder groups of retailers and wholesalers, and that the transformation of unsaleable products into waste still offers possibilities for obtaining revenues. Consequently, this research critically questions the proposition that unsaleable products are waste or waste resources. To the contrary, we propose that the instore logistics processes, as suggested by Kotzab and Teller (2005), should be extended towards the "afterlife" (logistics) of unsaleable products, in order to prevent such products being discarded and supply chain resources wasted. 
The aims of this paper are therefore twofold: First we want to explore the complexities of regularly implemented as well as irregularly occurring - sometimes improvised - instore logistics processes related to products which are declared unsaleable. Second, we want to identify the challenges and opportunities of managing instore logistics processes, related to unsaleable products in grocery stores. The units of our analyses are instore logistics processes from the identification of products as unsaleable to the recycling, disposal and redistribution of products.

Thus, the contributions of this research are (1) to provide a better understanding of different ways of seeing and handling unsaleable products and (2) to reveal the significant importance of focusing on in-store logistics beyond the point of sale with respect to the economic, ecological and social benefits to retailers, wholesalers and their stakeholder groups.

The remainder of the paper is structured as follows: After characterising the significance of the research gap in the instore logistics and store operations literature, we present a research framework that guides our explorations. The methodology of our case study research follows, and this leads to the presentation of the results. We then discuss our findings and present implications for theory and practice. The paper concludes with an outlook for further research.

\section{Literature Review}

The relevant literature base refers to several literature streams dealing with instore logistics, reverse logistics and food waste. Starting out with the existing body of knowledge related to instore logistics, we narrow down the view to the logistics of unsaleable goods.

The literature on instore logistics offers a lot of insight into the efficient management of all logistics processes at the point of sale, aimed at achieving a high level of consumer order fulfilment by ensuring demand-driven on-shelf availability (Fisher et al., 2000; Reiner et al., 2013). Instore logistics processes include all processes from those that take place at the unloading bay of a store onwards, namely the checking of the delivery, storage and transport, 
handling, shelf-stacking and replenishment, as well as return and disposal (see Figure 1;

Gudehus and Kotzab, 2012; Kotzab and Teller, 2005).

The work by Broekmeulen et al. (2004), Curseu et al. (2009) and van Zelst et al. (2009) pays attention to how the shelf-stacking and shelf replenishment processes affect efficient shelf availability. Out of this perspective, the notion of shelf-ready packaging has been developing, in which efforts are made to ensure that products are ready for sale when they arrive at a store (Bergmann, 2008). Consequently, the efficiency of instore logistics processes is improved as products' identification, product handling and shelf replenishment are accelerated (ECR Europe, 2006).

Furthermore, we see a strong focus on the prevention of out-of-stock situations rather than activities related to the unsaleability of products and the subsequent logistics processes (for an overview, see e.g. Corsten and Gruen, 2003; Ehrenthal and Stölzle, 2013). Other authors focus on store replenishment and the efficiency of store operations processes (e.g. Raman et al., 2001; van Donselaar et al., 2006; Reiner et al., 2013).

Within this literature stream, the issues related to unsaleable products are only marginally and implicitly considered in studies on "shrinkage", i.e. in terms of the loss of merchandise due to theft, fraud, administrative error, damage or wastage (Howell and Proudlove, 2007; Rekik and Sahin, 2012). Despite the crucial commercial cost-relevance of shrinkage at a store level, the logistics of unsaleable (food and non-food) products at the point of sale have been widely neglected in the instore operations and logistics literature.

Within the literature on reverse logistics, there is a distinction made between "end-of-life" and "end-of-use" products that are returned by consumers (Krikke et al., 2004). Gobbi (2011) introduces the term "product residual value", which is used to determine the return strategy of a company based on the remaining value of a returned product. The potential strategies include reconditioning (repairing, refurbishing, or remanufacturing), remarketing and disposal. The 
discussion on this aspect of the reverse flow refers to a supply-chain-wide perspective from an original equipment manufacturer's point of view, with a focus on electronic waste. When it comes to the design of reverse logistics systems for other commercial products, Blackburn et al. (2004) present different generic reverse logistics designs depending on whether a product is considered to be innovative or functional. Thus, following the notions of Fisher (1997) reverse channels can be organised in a responsive and efficient manner. Furthermore, Blackburn et al. (2004) distinguish between centralised and decentralised reverse channels, albeit remaining at the distribution-centre level of a (retail) supply chain. Insights into any reverse logistics activities at the point-of-sale level are not provided.

Tibben-Lembke and Rogers (2002) investigate reverse logistics processes in different retail sectors. They focus on customer returns in retail store, catalogue and online retail operations as well as on retailer and manufacturer returns to suppliers. The issue of unsaleability is addressed in terms of whether products are in a condition to be resold in another outlet, reconditioned, or donated to charity, or must be disposed of. The authors present a total flow model that includes reverse and forward product and information flows at an aggregated level, and do not examine what drives the decision regarding whether a product is still usable or not.

Autry et al. (2001) examine the reverse logistics processes in catalogue retailing for electronic goods and show that some companies deal with their reverse flows internally and others outsource the process to special logistics service providers. There is an indication that retailers dealing with such flows internally decide upon the saleability of returned products by checking the recovery and repair options for these products. However, their study does not examine the specific decisions and processes in regards to these issues at all. The authors examine the performance measures and the satisfaction with the performance.

Recently, Bernon et al. (2011) have examined the dimensions used for managing retail-specific reverse logistics and the existing approaches for managing reverse flows in a retail setting. 
Their starting point, however, is the return of a product and not its unsaleability at the point of sale. Even though they identify repair and refurbishment as potential actions for transforming unsaleable into saleable products, their discussion remains on a strategic and holistic level, as they introduce a general model consisting of process management, physical networks, organisational integration between functions, suppliers and customers, and management reporting and control.

The literature on waste management has considered the phenomenon of unsaleable products in a rather descriptive way but has recently received significant attention under the topic of food waste. Most of the research aims to quantify the significance of this phenomenon rather than investigate the logistics attached to it. The focus is on specific retail and wholesale markets, such as the European Union (European Commission, 2010), the United States (BSR, 2013; BSR, 2014; Jones, 2004), Austria (Schneider and Wassermann, 2004; Lebersorger and Schneider, 2014), Canada (Gooch et al., 2010), Finland (Katajajuuri et al., 2014), and the United Kingdom (Mena et al., 2014). Common to all those publications is that they do not provide an in-depth understanding of the various mechanics, such as drivers, solutions, or recovery or redistribution measures, involved at a store level. Within the context of food waste, Aiello et al. (2014) and Papargyropoulou et al. (2014) consider the issue in a wider supply chain context and discuss possible solutions in the form of waste avoidance and recovery. Stenmarck et al. (2011) focus on the food waste issue in the Nordic wholesale and retail sector but do not provide in-depth insights into the operational mechanics behind the waste issue or opportunities to redistribute the edible share of food waste. Finally, a very recent study by Lebersorger and Schneider (2014) quantifies the phenomenon of food waste at a retail level, taking into account different store formats. They also look into the phenomenon of returns and redistribution related to donations. Nevertheless, this research is of a purely descriptive nature and only gives an overview of the magnitude of the problem. They conclude that food loss rates - in terms of sales - vary between product categories and store types, for example, for 
fruits and vegetables shrinkage rates range from $1.2 \%$ to $14.7 \%$, for dairy products from $0.2 \%$ to $8.4 \%$, and for bread and pastry from $0.4 \%$ to $9.6 \%$. This study also highlights returns to suppliers, which are not included in shrinkage, mainly for bakery products, in the case of which between $7.5 \%$ and $15.1 \%$ of the sales value is returned to the suppliers. Further, food that is redistributed to charities makes up $0.18 \%$ of food declared unsaleable.

A very limited amount of literature focuses on the reuse and redistribution of unsaleable and edible food waste from grocery stores for disadvantaged consumers, examining charitable organisations such as social supermarkets and food banks (Holweg and Lienbacher, 2011). The focus of these works, however, is not on the logistics processes in grocery stores dealing with unsaleable goods but on the analysis of new forms of grocery retailing and their specific marketing characteristics.

\section{Research Framework}

Regardless of the level of rocket science retailing (Fisher et al., 2000) required to make a retailer's supply chain management successful, at the end of the day it is the local store management's efforts that determine success or failure in retailing (see Fisher, 2009). It is the successful execution of the instore operations that distinguishes profitable from non-profitable retailers (Raman et al., 2001). However, all retail store operations addressed by those authors refer exclusively to activities regarding the forward-directed flow of goods and relevant information, and they do not include processes that go beyond the point of sale.

Our literature review has identified only very limited existing research that has looked at inefficiencies in retail logistics with respect to store operations and processes related to the disposal, recycling and redistribution of food and non-food products. We see that it is necessary to assess a product's residual value, based on which certain decisions as to the extension of the product's sales process can be taken. So far, the "natural" push/pull boundary (in accordance with Chopra and Meindl, 2012) in a grocery retail environment has been the 
shelves in stores, where a retailer's product range choice meets the demand of the consumers. In the case of unsaleability, a reverse cycle is initiated within the store, and this so far has determined the procurement cycles of the retailers (Chopra and Meindl, 2012).

However, our literature review shows that there is no research to date looking at the necessary steps within instore logistics processes, the operations that deal with decisions over products' residual value, the potential return, and redistribution strategies. Kotzab and Teller (2005) provide a widely accepted model on instore logistics for grocery stores. Given the gaps our literature review has identified, we suggest widening the process " $\mathrm{H}$ : Disposal and Recyling" of that model, which we will use as a research framework (see Figure 1).

We propose to distinguish between (1) the logistics processes related to unsaleable products (labelled as process H1) and (2) the return logistics processes of the tertiary and secondary packaging, e.g. pallets, trays, boxes and other reusable packaging units (labelled as bprocess $\mathrm{H} 2$ ). The extended framework suggests that unsaleable products can appear at different stages of the instore logistics processes. These stages include the receipt and checking of the delivery (A), instore transportation and storage $(\mathrm{B}, \mathrm{C}, \mathrm{D})$ and - most importantly - the handling of the product on the sales floor. Based on this framework, we analyse the relevant activities at a process as well as at an activity level. We build on Gobbi's (2011) notions about product residual value and apply them in a store context. The residual value is seen to be the underlying measure in terms of a product being deemed unsaleable and processed in different ways. Next, we enlarge on the methodology we apply to investigate the logistics processes related to unsaleable products. 


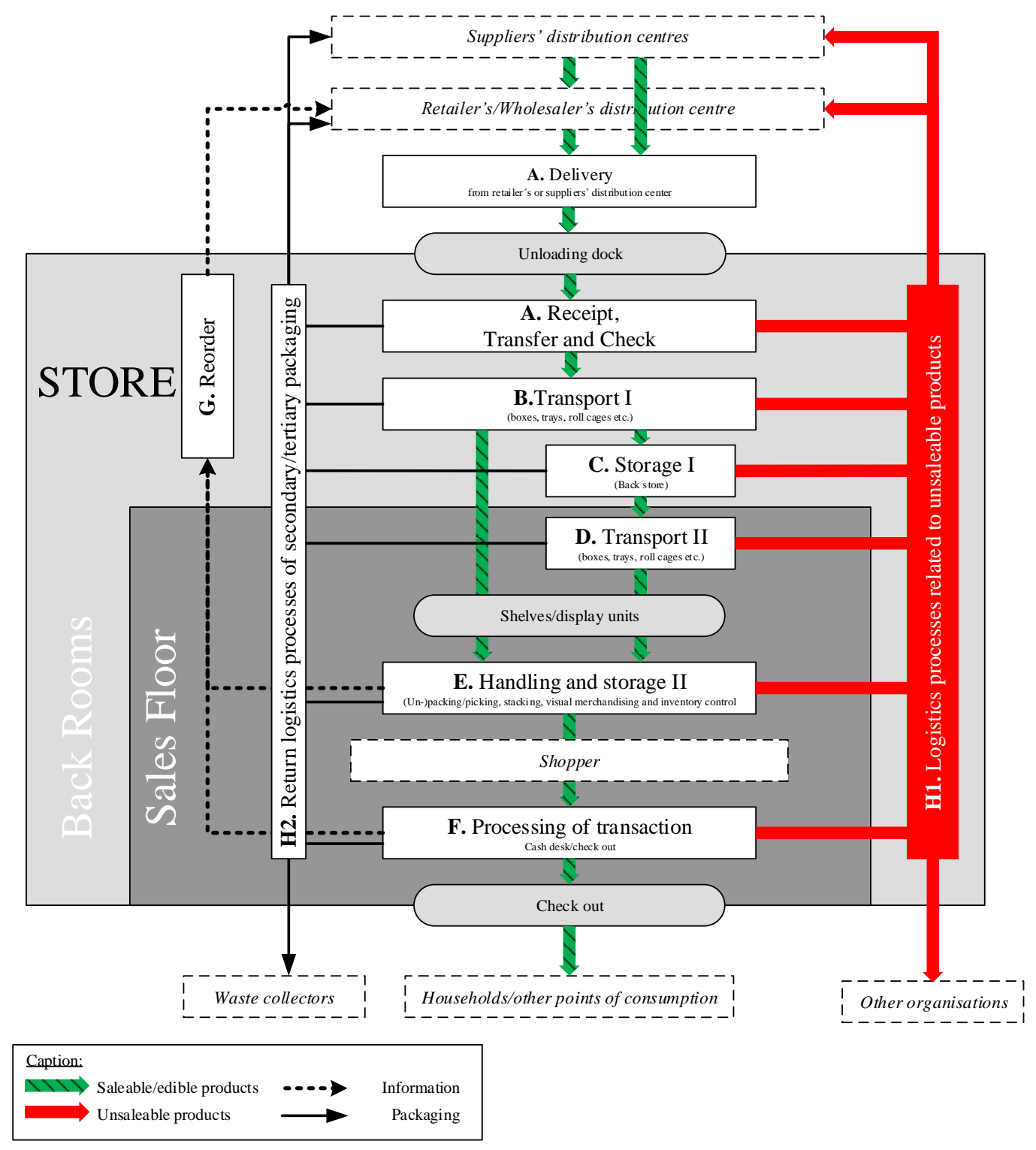

Figure 1: Instore logistics processes of saleable and unsaleable products

\section{Methodology}

With this research, we aimed to gain an in-depth insight and better understanding of the complexities of regularly implemented as well as irregularly occurring - sometimes improvised - instore logistics processes related to products which are declared unsaleable. Consequently, we applied a case study approach, a method being used increasingly in operations management research (Barratt et al., 2011), and we heeded the notions of Stuart et al. (2002), in particular at the data-gathering and analysis stages of our research. The units of analysis are the logistics processes related to unsaleable products in the various store formats, i.e. store configurations 
characterised by typical combinations of store resources and capabilities, for example, location, space (size), number of categories (width of product range), number of stock-keeping units (SKUs) within each category (depth of product range), quality and pricing of products, and service level (Reutterer and Teller, 2009). Given the high level of standardisation of such retail and wholesale formats, we considered four cases to be the minimum needed to achieve data saturation for our purposes (Guest et al., 2006). The final sample consists of 32 stores from 6 different organisations, divided into retail stores, including convenience stores (4 stores/2 organisations), discount stores (5/2), supermarkets (11/3), and hypermarkets (8/2), and wholesale stores, which refers to cash and carry stores (4/3). Table 1 outlines the case characteristics including, e.g., store size, number of employees, and product range in terms of SKUs offered. Given their operational responsibility - and thus expertise - in store operations, we targeted store managers as our key informants (Campell, 1955), after gaining official approval from their headquarters. Given that obtaining the opinions, perceptions and evaluations of managers on a rather operational level was imperative, a mainly qualitative design was considered the most suitable approach for knowledge generation (Gummesson, 2005). Furthermore, qualitative research is particularly helpful in situations where a real-life context is important (Sinkovics et al., 2005). To this end, semi-structured interviews with the store managers were conducted to gain "a more accurate and clear picture of a respondent's position or behavior" (Ghauri and Gronhaug, 2002, p. 101) and so as to elaborate on the interesting perspectives offered. An interview guide was necessary since managers at such an operational level are under significant time constraints. The interview guide was based on the research framework depicted in Figure 1. In our interviews, we emphasised the processes and activities related to products being declared unsaleable on the sales floor (see processes D and E in Figure 1).

The field work was conducted by three interviewers over a period of two months. The first interview in each store format was led by two interviewers, allowing them to reflect on 
potential insights for later interviews. All interviews took place in the stores, usually in the back office of the store manager, next to the sales floor. On average, an interview lasted 43 minutes, and observations of food waste storage rooms took an additional 15 minutes, concluding the investigation.

\begin{tabular}{|c|c|c|c|c|c|}
\hline $\begin{array}{l}\text { Distribution } \\
\text { level/store } \\
\text { format } \\
\text { (standard } \\
\text { deviation) }\end{array}$ & $\begin{array}{l}\text { Number of } \\
\text { interviews }\end{array}$ & $\begin{array}{l}\text { Floor space } \\
\qquad\left(\mathrm{m}^{2}\right)\end{array}$ & $\begin{array}{l}\text { Full time } \\
\text { equivalent } \\
\text { employees }\end{array}$ & $\begin{array}{c}\text { Customers per } \\
\text { day }\end{array}$ & $\begin{array}{l}\text { Product range } \\
\text { (\# of SKU) }\end{array}$ \\
\hline \multicolumn{6}{|l|}{ Retail } \\
\hline Supermarket & 11 & 456 (194) & $11(5)$ & $920(342)$ & 8,000 \\
\hline Hypermarket & 8 & $1,905(550)$ & $52(36)$ & $1,458(1,381)$ & 14,000 \\
\hline Discount store & 5 & $646(165)$ & $7(2)$ & $1,517(893)$ & 2,000 \\
\hline $\begin{array}{l}\text { Convenience } \\
\text { store }\end{array}$ & 4 & $197(36)$ & $14(11)$ & $145(2,352)$ & 1,400 \\
\hline \multicolumn{6}{|l|}{ Wholesale } \\
\hline Cash and carry & 4 & $5,900(1732)$ & $88(52)$ & 403 (130) & 15,000 \\
\hline
\end{tabular}

Table 1: Case characterisation

The qualitative analysis was based on 23 hours of interviews, which resulted in 423 singlespaced A4 pages of transcripts. Data from the instore observations, together with 63 pictures, were also included in the coding and analysis process. First, each case was analysed, including its case description, the interpretation of the decision process, and the differentiation between types of unsaleable products. Content analysis of the textual data and visual elements was applied. This analysis approach helps to classify textual and visual material, reducing it to more relevant, manageable details (Weber, 1990). The approach used for the analysis refers to Mayring (2000) and to Krippendorff (2004) and ensures the quality of the analysis in terms of stability of coding, reproducibility and accuracy. To master the significant amount of data gathered, we utilised computer-assisted qualitative data analysis software (QSR NVIVO 10) in the coding process (Flick, 2009). The textual data were triple coded in three coding rounds by the members of the research team - all of whom had experience with text coding from previous 
projects - ensuring inter-coder reliability in terms of stability, reproducibility and accuracy related to the coding process (e.g., Creswell, 2009). After each coding round, the results were discussed and the coding scheme was adapted and standardised for all coders. The decisions as to which direct quotes should be included in this manuscript to support the argumentation were made jointly by the members of the coding team. Overall, these coding endeavours resulted in more than 3,300 coded references. To meaningfully present our results in this paper, we use process diagrams and tables. Furthermore, we use the aforementioned direct quotes to support our claims but also to illustrate our findings by putting them in the context of specific store format settings (e.g., Berg and Lune, 2012).

\section{Results}

The results are presented in four sections. Firstly, we describe the relevant decision processes related to instore logistics up to the stage at which products are declared unsaleable. Based on that, we further identify different dimensions of unsaleability, and the subsequent processes and decisions related to the logistics of products being declared unsaleable. Lastly, we highlight the potential for the efficiency of instore processes to be optimised or increased.

\subsection{Instore logistics decisions from delivery to the declaring of products as unsaleable}

\subsubsection{From delivery to the selling of the products}

Figure 2 depicts those instore logistics processes that occur between delivery to the store (see Process 1: "Delivery to the store") and the identification of unsaleable products within the store (see Decision 5: "Product saleable?"). The identified processes are independent from the store format and include activities and processes dedicated to making products available at the point of sale and giving them the best chance of being sold (see Process 2: "Instore logistics"; Kotzab and Teller, 2005; van Donselaar et al., 2006; Reiner et al., 2013). From our interviews we found that the inherent, paramount aim behind those processes is to provide sufficient onshelf availability and reduce the opportunity costs related to out-of-stock situations (Ehrenthal 
and Stölzle, 2013). In most cases products are sold (see Decision 3: "Product sold?") and consumers undertake the logistical effort required to deliver them to the point of consumption (see process 4: "Shopper logistics"; e.g., Granzin and Bahn, 1989; Teller et al., 2011). In the case of products not selling as expected, store managers check that they have not surpassed their shelf life and an attempt is made to push slow-moving stock out by providing additional stimuli for demand. Such slow-selling products represent a key challenge for store managers. Both retailers and wholesalers regard selling products off at a reduced consumer price as the most effective strategy for reducing the amount of unsaleable products at a store level across most product categories, as the manager of a discount store explained:

"The only option is price reductions. It is the action most suitable for keeping food waste as low as possible." (Discount store, case 25)

Marked-down products are displayed in particular areas in order to increase their visibility and thus sales. Discounts are usually implemented as reductions from the regular item price (e.g., $10 \%$ off, $30 \%$ off) or as multi-pack promotions (e.g., buy one get one free). Some managers increase the price reduction incrementally as the product expiry approaches, as explained by a manager of a cash and carry store:

"We start with a discount of 10\%, then we offer 25\% and finally 50\%." (Cash and carry store, case 29)

However, price discounts vary across categories. Meat products seem to be the category for which price reductions are least successful. Looking at the wholesale level, store management also has the option of conducting so-called "active personal selling", since all business customers are registered in their databases. One manager decribed this "push" approach as follows: 
"We can filter out who is buying the respective articles and we then call them saying we have excess stock ... and we offer it at a reduced price." (Cash and carry, case 32)

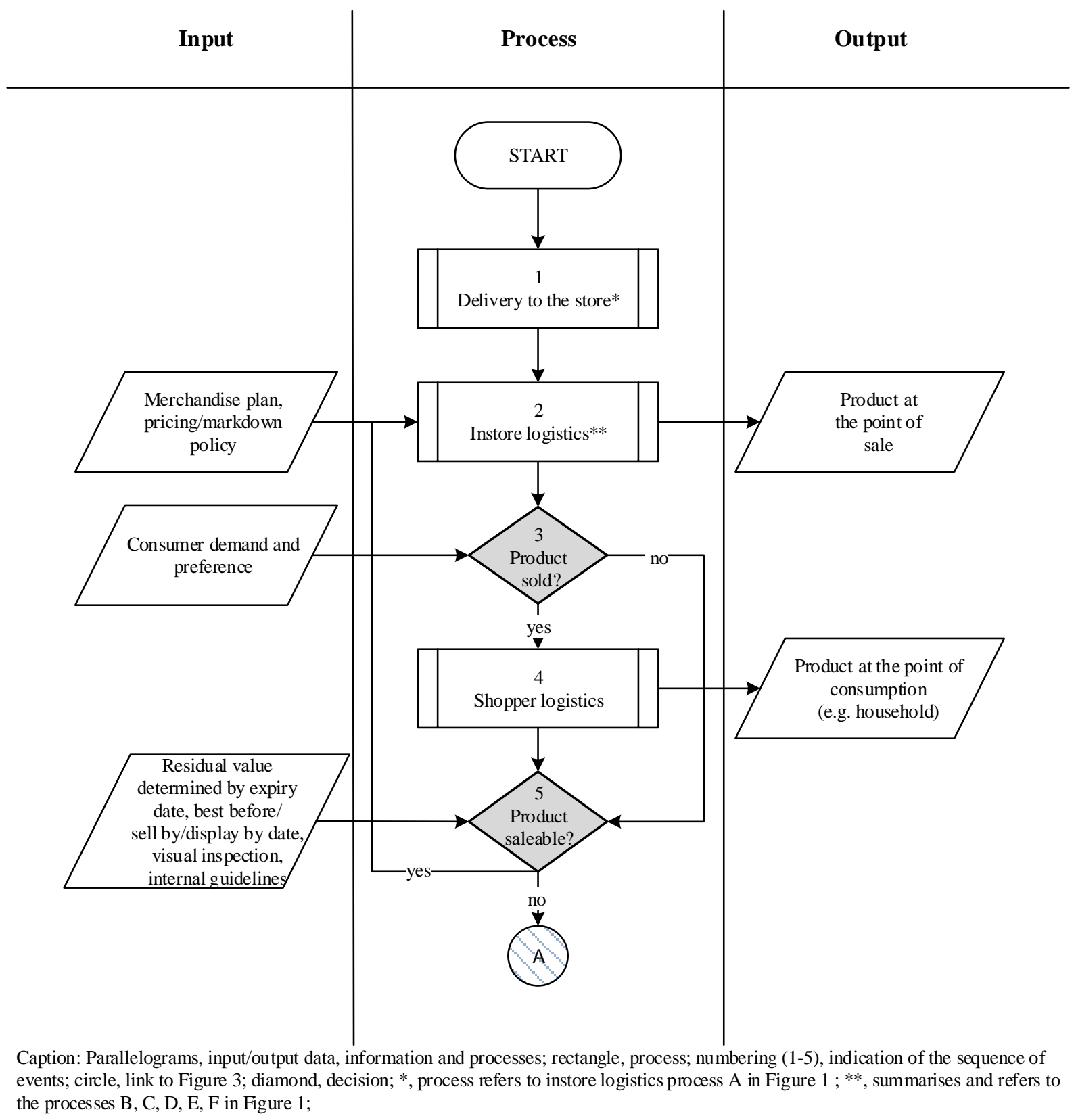

Figure 2: Instore logistics processes from delivery to identification of unsaleable products

Thus, wholesale organisations use their sales departments, allowing them to react earlier than retail organisations in selling off products that are at the end of their shelf life. This unique 
opportunity contributes to lower shrinkage numbers and a lower rate of unsaleable products in the wholesale sector.

If mark-downs are not effective for the stores in terms of selling merchandise at the end of their shelf life, store managers have to deal with the question of whether the product is still saleable or not (see Decision 5: "Product saleable?" in Figure 2). If a product can no longer be sold, it must be declared unsaleable and its value is written off as shrinkage. Shrinkage rates vary significantly between product categories and store formats. Table 2 presents (1) a ranking of the quantity of food waste occurring in stores based on the estimations of store managers, and (2) the shrinkage rates in percentage of sales value, derived from secondary data collected from merchandise information systems during our interviews.

These rates give an indication of the magnitude of the issue and the potential for the redistribution of products, which will be discussed below. For example, the category of fruits and vegetables accounts for the largest quantity of food waste across all retail formats, and is ranked second in the wholesale sector, i.e. cash and carry stores. The respective shrinkage rates range from $0.5 \%$ in cash and carry stores to $15.0 \%$ in supermarkets. The ranking of these categories as well as their high variances across different store formats is in line with the findings of the recent study by Lebersorger and Schneider (2014). Given that profit margins in grocery retailing and wholesaling are very low, the stated shrinkage rates illustrate the commercial but also the ethical dimension of unsaleable products in grocery retailing and wholsale. It is also worth mentioning that most of the interviewees referred to shrinkage as a store's key performance indicator, which subsumes the value of the physical products that are declared unsaleable as well as the loss in value due to markdowns. 


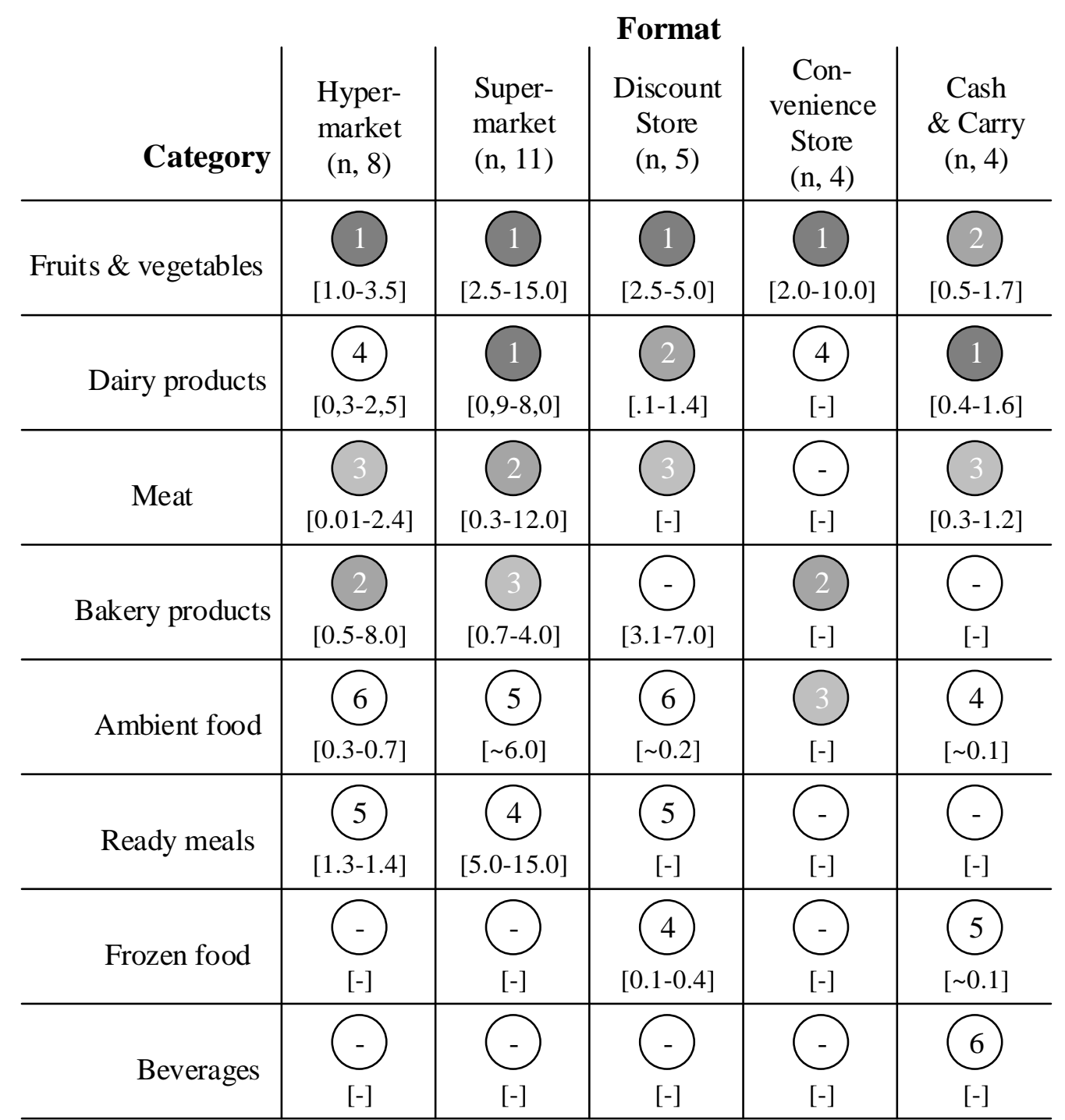

Notions: The encircled numbers refer to the ranking offood categories that show the highest proportion of food waste occurrence (in terms of volume); the numbers in the squared brackets represent the shrinkage defined by the share of sales value per category; $n$, number of cases;

Table 2: Ranking of shrinkage rates per product category and food waste

When it came to the question of the degree to which the shrinkage and unsaleability of products affects the profitability of product categories and the store, we were confronted with some limitations, as profitability ratios are unavailable to store managers. Several store managers told us that they had access to net sales in their merchandise information systems but could not retrieve information on profit margins as it would require data on the net purchase price which was not disclosed by their headquarters. Nevertheless, the identified shrinkage rates give some indication of the impact unsaleability of products has on profits. 


\subsubsection{From declaration of unsaleability to redistribution, discarding, recycling and return}

Following on from from Decision 5 ("Product saleable?") in Figure 2, we now outline what happens to a product that has been declared unsaleable, in Figure 3. The reasons for products being considered unsaleable and thus withdrawn from the point of sale are manifold. Our interviewees mentioned the following most frequently: (1) legal reasons (products reaching their expiration date), (2) breakages (packaging faults caused by employees during handling and consumers during shopping), and (3) high quality standards (internal guidelines of retail organisations). This set of reasons extends the list of root causes of waste in the food supply chain reported by the European Commission (2010).

Inspecting the rest of the process, we were able to observe that the product's residual value plays a major role. Depending on their condition and value (see Decision 6: "Product returnable?”) - as evaluated by store personnel - these items are either returned, recycled, discarded or redistributed. This goes along with the strategies suggested by Gobbi (2011).

\subsection{Edibility versus redistributability}

The results in Figure 3 focus on the three processes of redistribution (9), recycling (11) and disposal (12), which are especially related to the logistics of unsaleable food products. Our interviewees distinguished between two characteristics and thus between different levels of residual values of unsaleable products that cannot be returned to the retailer's and supplier's distribution centre. 


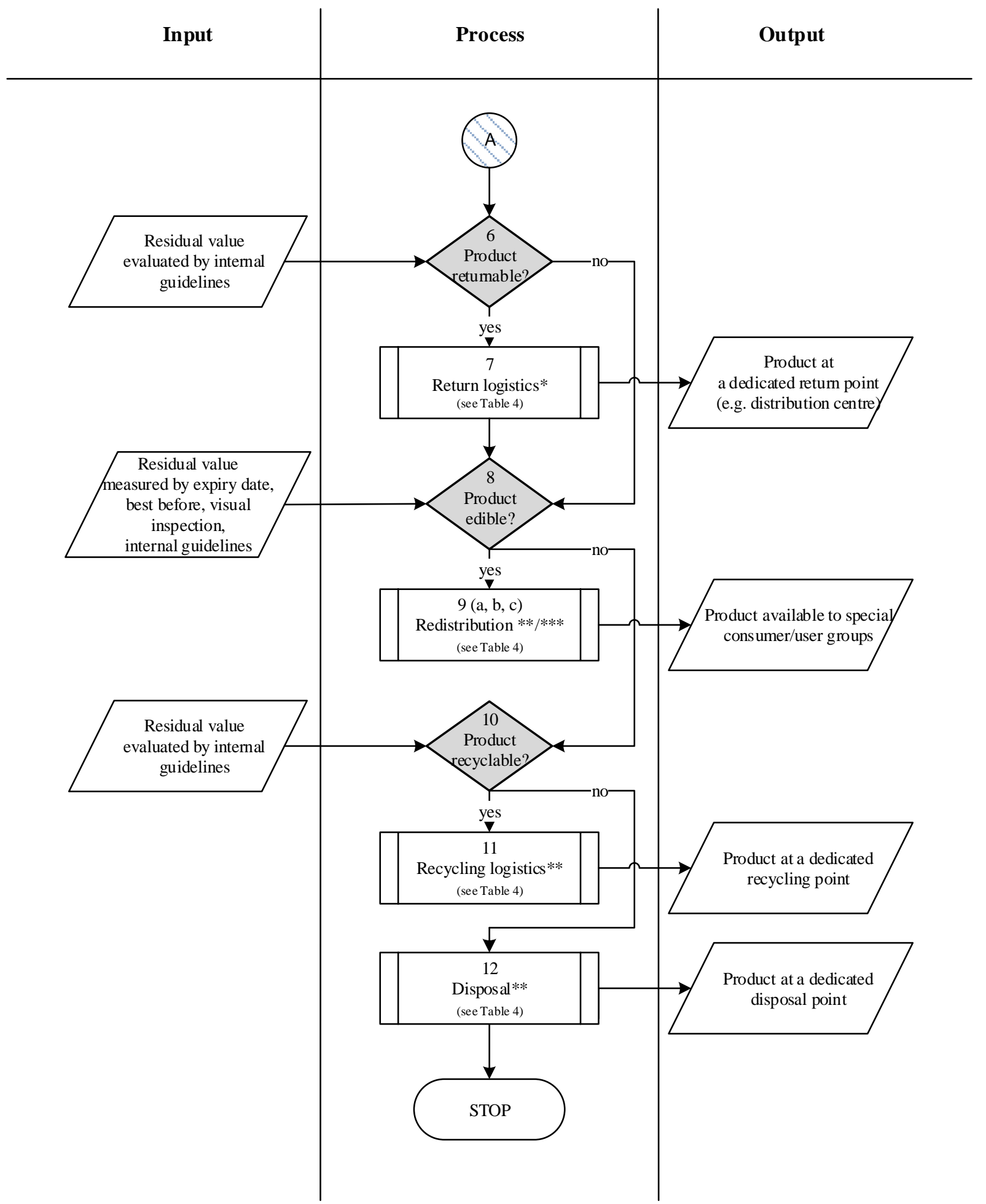

Caption: Parallelograms, input/output data, information and processes; rectangle, process; numbering (6-12), indication of the sequence of events; circle, link to Figure 2; diamond, decision; *, process refers to instore logistics process $\mathrm{H} 2$ in Figure 1 ; **, refers to the instore logistics process $\mathrm{H} 1$ in Figure 1; ***, subsumes internal, social and other distribution processes as described in Table 4;

Figure 3: Instore logistics processes from unsaleability to disposal

The first is the edibility of products, which refers to whether unsaleable products are fit (of sufficient quality) for consumption by human beings. Second, store managers mentioned 
characteristics related to the redistributability of unsaleable products, which takes into account opportunities for retailers or wholesalers to pass these products on for further use and consumption. For example, products declared unsaleable might be partly edible, but parts of them might have to be disposed of, such as fruits affected by mould. Unsaleable and edible products might not always be redistributable, if the quantities are too small to justify a collection economically, or if product safety cannot be ensured. The edibility and redistributability of unsaleable products thus strongly depend on the respective food categories. Within the fruits and vegetables category, the interviewees estimated that between $50 \%$ and $70 \%$ of all unsaleable products were still edible, of which the majority would still be redistributable (see Table 3). In the dairy category, they estimated that the edible percentage of unsaleable products was $90 \%$; a majority of those products were regarded edible. The manager of a hypermarket described the issue of the edibility of unsaleable products using the example of dairy products:

“... [with dairy products] all are edible in principle. Even when the exiry date is reached, products are still all right for between three and five days beyond that date." (Hypermarket, case 2)

\begin{tabular}{lcc}
\hline Category & Edible & Redistributable \\
\hline Fruits and vegetables & $50 \%-70 \%$ & Majority \\
Dairy products & $50 \%-90 \%$ & Majority \\
Meat & $20 \%-70 \%$ & Minority \\
Bakery products & $40 \%-100 \%$ & Majority \\
Ambient food & $100 \%$ & Majority \\
Ready meals & $80 \%$ & Minority \\
\hline
\end{tabular}

Table 3: Estimates of the proportions of all unsaleable food products that are edible and redistributable 
With fruits and vegetables, our interviewees estimated that between $50 \%$ and $70 \%$ of all unsaleable products were still edible, of which the majority would still be redistributable. Inedible and thus unredistributable products include those with major breakages and mould. Turning to meat products, the percentage of unsaleable products that are still edible is much lower, ranging between $20 \%$ and $70 \%$. A continous cold chain and thus impeccable product quality is considered as paramount in this product category given the potential health risks involved. The manager of a discount store emphasised the quality requirements related to chilled and frozen products as follows:

"One has to be very cautious ... if products are left outside [of cooling facilities] ... and someone consumes them, that may have detrimental consequences for this person and for the company. I do not find that a good idea. The cold chain is essential ... we should not play around with that." (Discount store, case 24)

In the category of ready meals, it is estimated that around $80 \%$ of products declared unsaleable are still edible. Given the short expiration dates and cooling requirements, however, only a small share of products in this category can be redistributed for further consumption. Unsaleable frozen food and beverages were rarely mentioned as being edible and redistributable, simply because these categories are the least frequently declared unsaleable. These results and the distinctions between different types of unsaleable products reflect the views of numerous publications on food waste management (e.g., Stenmarck et al., 2011; Lebersorger and Schneider, 2014; Mena et al., 2014).

5.3. Returning, discarding, recycling and redistributing processes for unsaleable products, depending on the products' residual value

We identified 14 distinct individuals and organisations as recipients of products that had been declared unsaleable. As such, these recipients represent subsequent stages of the supply chain (see Roman numerals in Table 4). We related these recipients to the four processes involving 
unsaleable products, as outlined in Figure 3, i.e. return logistics (7), redistribution (9), recycling (11) and disposal (12). It is worth mentioning that we did not find all processes implemented in all of the stores investigated.

The first group of recipients (I and II in Table 4) are involved in the return logistics of unsaleable products, which represents the highest residual value for retailers and wholesalers. The products here are returned to the suppliers and do not remain in the store. Return processes mainly involve products that are delivered directly to stores by suppliers, such as bakery products and meat. The unsaleable products are collected by the suppliers on their next delivery cycle from the back storage room of the store where they are kept in specifically marked boxes. Returns do not affect a store's key performance indicator, "shrinkage", as the value of the returned product is fully credited to the store's accounts. This return process is found in the majority of hypermarkets as they receive direct store deliveries on a daily basis. None of the discount stores investigated had implemented such return processes.

We next found three distinct processes of redistribution related to unsaleable products with a medium residual value, involving different recipient groups. These products are still edible and can be used for further processing but are seen as unfit for further sales. The three processes are internal redistribution (9a), social redistribution (9b) and other redistribution (9c), as outlined in Table 4.

Internal redistribution refers to product flows and transformation processes by which unsaleable products are sent to fresh food counters (III) and restaurants (IV), for example by making juice from slightly blemished fruits. The manager of a hypermarket explained this internal redistribution process as follows:

“... we can also process fruits and vegetables. We prepare food to go ourselves, salad you can also process... and there are juices that can be prepared... you can 
use lots [of unsaleable products] and this improves your sales and actually your margin..." (Hypermarket, case 3)

Such ready-to-eat products thus offer opportunities for stores as they reduce the amount of food products that would normally be disposed of and written off, and at the same time have a positive impact on a store's profits. Stores can achieve this by charging higher prices for take away products than regular, unprocessed products. Other recipients involved in internal redistribution processes are other stores $(\mathrm{V})$ and store staff to whom unsaleable products are given away. Internal redistribution processes sending products to fresh food counters and restaurants were found in all store types that offered these services, i.e. primarily hypermarkets and some wholesale stores as well as larger supermarkets.

We identified social and welfare institutions as another group of recipients of unsaleable products. Almost all retail and wholesale organisations have established official social distribution processes to pass on unsaleable, but still edible, products to charities such as food banks (VII) and social supermarkets (VIII). Products are collected in the cold storage room in specially marked boxes. Employees of these charities pick these products up according to a prearranged fixed schedule or following a call from the store manager. The store manager of a supermarket decribed the social redistribution process as follows:

"We cooperate with a social supermarket and products are collected on a daily basis... in the past we had to throw everything away...this now is a good solution, things do not end up as waste. And it actually goes to people who really have a need for it." (Supermarket, case 11) 


\begin{tabular}{|c|c|c|c|c|c|}
\hline \multirow{2}{*}{$\begin{array}{l}\text { Processes } \\
\text { (see reference to } \\
\text { output in Figure 3) }\end{array}$} & \multirow[b]{2}{*}{ (7) Return logistics } & \multicolumn{3}{|c|}{ (9) Redistribution } & \multirow{2}{*}{$\begin{array}{l}\text { (11) Recycling/ (12) } \\
\text { Disposal }\end{array}$} \\
\hline & & $\begin{array}{l}\text { (9a) Internal } \\
\text { redistribution }\end{array}$ & $\begin{array}{l}\text { (9b) Social } \\
\text { redistribution }\end{array}$ & $\begin{array}{l}\text { (9c) Other } \\
\text { redistribution }\end{array}$ & \\
\hline \multirow{4}{*}{$\begin{array}{l}\text { Recipients of } \\
\text { unsaleable } \\
\text { products }\end{array}$} & $\begin{array}{l}\text { (I) Suppliers (bakery } \\
\text { products, meat) }\end{array}$ & (III) Fresh food counter & (VII) Food banks & $\begin{array}{l}\text { (X) Animal welfare } \\
\text { institutions }\end{array}$ & $\begin{array}{l}\text { (XII) Waste collector } 1 \\
\text { (residual waste) }\end{array}$ \\
\hline & \multirow[t]{3}{*}{$\begin{array}{l}\text { (II) } \\
\text { Warehouse/distribution } \\
\text { centre }\end{array}$} & $\begin{array}{l}\text { (IV) Restaurant and } \\
\text { catering }\end{array}$ & $\begin{array}{l}\text { (VIII) Social } \\
\text { supermarkets }\end{array}$ & $\begin{array}{l}\text { (XI) Private use (for } \\
\text { composting or animal } \\
\text { feed) }\end{array}$ & $\begin{array}{l}\text { (XIII) Waste collector } 2 \\
\text { (organic waste) }\end{array}$ \\
\hline & & $\begin{array}{l}\text { (V) Other stores within } \\
\text { the retailer's } \\
\text { organisation }\end{array}$ & $\begin{array}{l}\text { (IX) Communities } \\
\text { (social events, } \\
\text { sponsoring, neighbours) }\end{array}$ & & $\begin{array}{l}\text { (XIV) Waste collector } 3 \\
\text { (meat waste) }\end{array}$ \\
\hline & & \multicolumn{3}{|l|}{ (VI) Employees } & \\
\hline $\begin{array}{l}\text { Residual value } \\
\text { of products }\end{array}$ & High & ledium & dium & Low & Low \\
\hline Benefits & $\begin{array}{l}\text { - Economic } \\
\text { - Ecological }\end{array}$ & $\begin{array}{l}\text { - Economic } \\
\text { - Ecological } \\
\text { - Social }\end{array}$ & $\begin{array}{l}\text { cological } \\
\text { cial }\end{array}$ & - Ecological & - Ecological \\
\hline
\end{tabular}

Table 4: Logistics processes related to unsaleable products 
Such processes, whereby charitable organisations collect unsaleable food from stores, often on a daily basis, are mainly found at hypermarkets and wholesale stores of a larger size, where the amounts of unsaleable food are higher. In supermarkets, where the quantities of unsaleable food are lower, daily collections do not take place. Here, trucks delivering products to stores return unsaleable products to the distribution centres, and charities collect products from them on a regular basis. As such, this process represents both a return process and one of redistribution to social organisations. Overall, discount and convenience stores exhibited fewer instances of social redistribution to charities.

Redistribution to social organisations often implies that a written statement has been drawn up between the retailer's headquarters and the charity, in which the acceptance of product liability is agreed. Products passed on by retailers and wholesalers to charities are usually provided for free. In some instances, managers stated that they gave away unsaleable products to their local community and supported social events and close neighbours in need (IX). The liability for food safety would in that case remain with the store manager, and thus the retail or wholesale organisation respectively.

We also found other redistribution processes occurring in the investigated stores, through which products are passed on to various kinds of recipients for non-human consumption. This includes, for example, farmers and animal welfare institutions (X), who feed fruits, vegetables and bread to animals such as horses, monkeys and small pets. The store manager of a hypermarket described this redistribution process as follows:

“... mainly bread and bakery products which can still be consumed are collected by a children's home and a social supermarket. The remainder ... well they do not come by every day [but they] are taken by farmers for pigs and horses, and fruits and vegetables are all taken by the local animal welfare house." (Hypermarket, case 1) 
Other redistribution processes like this were found in very few stores and mainly seem to have been established through the private initiatives of store managers. For example, one manager of an independent convenience store used excess fruits and vegetables for the private purpose of producing compost (XI).

Finally, there are unsaleable products that cannot be passed on in any way and need to be declared as waste and discarded through the conventional waste disposal process. Such products are either recycled or discarded. All of the organisations were found to implement a dual disposal and recycling process, i.e. (XII) residual waste and (XIII) organic waste, which is a legal requirement. The two kinds of waste are collected in separate containers at the rear of the stores. Organic waste includes all types of fruit, vegetables and bread, which are unpacked before being placed into the relevant containers. Several organisations also put dairy products such as yoghurt in with organic waste, which requires it to be separated from all packaging. The majority of the stores were found to have established a third kind of waste process for meat (XIV). These products are collected in the cold storage area and in deep freezers located in the back-storage area to prevent the formation of bacteria. The manager of a supermarket summarised the recycling and disposal process as follows:

"We have two separate [containers], one for organic waste and one for residual waste that is for all the remaining waste, and then for meat a deep freezer..." (Supermarket, case 9)

The containers of the aforementioned three types of waste are collected by disposal companies every one to three days. Notably, all three types of waste can include both edible and unedible food if no redistribution processes are installed and no collection by charities takes place.

To summarise, the store format and the store characteristics behind it, e.g. size, product range, location, are key influencing factors, partly defining the scope and scale of the various processes. Overall, large store formats such as hypermarkets and wholesale stores represent the 
biggest opportunities to realise the potential related to the effective and efficient management of unsaleable products. For smaller stores such as supermarkets and convenience stores, the scale and thus the opportunities related to redistribution processes are limited as collection is more costly due to the smaller quantities involved. Discount stores with very simple and efficient supply chain processes and high cost pressures have less flexibility for setting up additional processes for unsaleable products.

\subsection{Challenges and opportunities of redistribution}

Our findings lead to the question of why it is that not all products declared unsaleable but edible and redistributable are passed on for further consumption or reuse. We identified four groups of challenges and opportunies, which can be classified into internal and external barriers:

Internal barriers: The most frequently mentioned internal and overall barrier was the lack of a process that had been commonly defined and approved by headquarters, allowing them to pass on products. The manager of a supermarket illustrated this issue as follows:

"Our stores was selected by the headquarter, in that some may pass on products, some not. Even if I said I would drive to this charity [name stated] and hand it over personally, [I would] not [be] allowed to do that. Only when we receive permission [from the headquarters] can we pass them on." (Supermarket, case 9)

This barrier refers to the clarification of the legal situation regarding product liability when products are handed over to an external partner. This requires the involvement and permission of the headquarters as store managers are not given the power to make such decisions. Linked to this barrier is the administrative effort and time required to set up written agreements and processes. One manager stated that, given his daily workload, he saw no chance of being able to initiate this process on his own (Cash and carry, case 5). 
A further internal barrier mentioned was restrictions set by the headquarters regarding discounting products close to expiration dates, which limits the store managers' flexibility when it comes to selling products off on time. This includes, for example, the practice adopted by some retail organisations of repackaging products whose packaging has been damaged. Another practice that was mentioned involved the provision of a small device for repacking fruits or vegetables in nets in store, as described by the store manager of a supermarket:

"Well, you have three partly broken packs... and you repack it into two. In the past you threw away all three, now you only write off one and throw away one. This is since last year, as our company jumped on this [preventing food waste occurence] and realised that it was important to prevent food spoilage." (Supermarket, case 11)

A further example of an internal restriction is explicit orders from the headquarters' that a store must not pass on any privately labelled food products. While the store manager in question could not give an explanation for this restriction, we assume that surplus product is seen as an indicator of insufficient demand and customer preference for a (retail) brand. The retail organisations would be making this public if they allowed their brands to be redistributed.

External barriers: The most common external barrier is legal limitations linked to food safety. The abovementioned instore counters at which products can be processed (e.g., fruits turned into juices) need to follow certain regulatory provisions and require specific facilities and infrastructure, which can be difficult to provide in supermarkets and convenience stores. Lastly, the lack of professionalism of receiving institutions can limit the opportunities and willingness of store managers to pass on products, and can even put an end to established cooperations, as described by the store manager of a hypermarket:

"There are some organisations that come here half an hour before you close and take products off the shelves themselves. ... I have customers from an affluent 
catchment area and they did not like this. ... I had to stop these organisations." (Hypermarket, case 4)

To conclude, these barriers to the efficient and effective management of the logistics related to unsaleable products reveal opportunities for our informants that would produce benefits for different stakeholder groups of retail and wholesale stores, in particular welfare institutions and waste collectors. These opportunities become obvious with regards to the impact on the costs and benefits related to the redistribution of products that are still edible. Our interviewees see no costs related to the preparation of unsaleable products for pick-up by charitable organisations. The manager of a supermarket put this as follows:

"The process stays the same, whether I put it into a box or dispose of it in a container. The effort stays the same. And even if it was more effort, I think nobody would have a problem because we would know that the products were arriving where there was need." (Supermarket, case 10)

Several interviewees even highlighted the various benefits of redistribution, such as this manager of a cash and carry store:

"From a commercial point of view the costs of handling and disposal are eliminated. And, you do not cannibalise your own sales ... because the people who shop in a social supermarket do not shop in regular grocery stores anyway."

(Cash and carry, case 29)

In addition to the positive effects on the costs of disposal and handling, i.e. separating packaging material from food that needs to go into a container for organic waste, the interviewees also saw the ecological benefits as well as social benefits for employees at a store level. The manager of a convenience store described the ethical dimension of such benefits as follows: 
"The benefit in my opinion are considerable. I mean these are perfectly fine products, which do not end in disposal any more ... it is a comfortable feeling when you are not wasting all of that any more." (Convenience store, case 12) To conclude, while not explicitly mentioned by our interviewees, the stated benefits overall very much depict the three pillars of the triple bottom line of corporate social responsibility for retailers and wholesalers, i.e. economic, ecological, and social benefits, related to the redistribution of unsaleable but still edible products from retail and wholesale stores.

\section{Discussion and Implications}

The instore logistics of fast-moving consumer goods are particularly driven by a short shelf life, the extensive requirements of grocery shoppers regarding on-shelf availability, price and quality, and the high pressure on costs and margins in this highly competitive store-based grocery channel (Reiner et al., 2013). Our examination of instore logistics-related processes and decisions regarding the unsaleability of products in a grocery retail and wholesale context has shown that the efficient management of unsaleable products - compared to that in other retail and wholesale sectors - is uniquely challenging. The challenges relate to the identification of the products' degree of unsaleability and residual value, and thus to the appropriate forward and reverse supply chain operations and strategies (see Table 4). Bearing in mind the significant challenge this phenomenon poses to our case settings, we are able to derive the following implications for theory and practice from our research.

\subsection{Implications for theory}

Extending the scope of logistics, both instore and beyond the point of sale: This research extends and critically questions the view that a store needs to be highly efficient and that the ultimate goal of store operations is the provision of a satisfactory (for customers) service level in terms of on-shelf availability for the lowest cost possible (e.g. Raman et al., 2001; van Donselaar et al., 2006, 2010; DeHoratius and Raman, 2007; Fisher, 2009). Using Fisher's 
(2009) characterisation of a store as a combination of a factory and a sales office, we add that stores also produce by-products during the sales process in the form of unsaleable products. Such by-products seem to be - according to the retail logistics, store operations and marketing literature - unwanted occurrences that reveal inefficiencies in the ordering and replenishment processes (e.g. Reiner et al., 2013). However, the literature examines to a significant degree the forward-directed flows up until products are shelved. With this research, we propose the inclusion of backwards-directed product flows, and challenge the order decoupling point by proposing value-adding processes depending on the residual value of unsaleable products. More specifically, and following Kotzab and Teller's (2005) view on the reverse processes of an instore logistics system, Gobbi’s (2011) idea of product residual value and Papargyropoulou et al.'s (2014) notions on a food waste hierarchy, we identify four groups of logistics processes - subsequently splitting them up into fourteen based on the different recipients - related to products that are declared unsaleable, i.e. returns, disposal, recycling and redistribution. In summary, our first theoretical contribution is to reveal the mostly inofficial and often improvised activities and processes that are hidden behind "umbrella key performance indicators" such as shrinkage. In other words, we are able to show that a retailer's or wholesaler's supply chain and logistics processes do not end at the point of sale and need both further theoretical as well as practical consideration.

Characteristics of unsaleable products in stores: The outcome of the investigation illustrates the complexity of logistics processes beyond the point of sale in retail and wholesale stores. These processes entail not only the handling, transportation and storage of unsaleable products but also the definition of the products' residual value and the identification of characteristics of unsaleable products in terms of edibility - synonymous with usability in a non-food setting - as well as distributability. The insights from our case studies show that - in the case of groceries the share of unsaleable products that are edible (or usable) is significant, which makes it sensible for such products to be returned to the suppliers, or the retailer's or wholesaler's 
distribution centres, sent on to other branches, or redistributed. This finding clearly confirms the conclusions of the European Commission (2010) that too much food waste is being produced and too much edible food discarded at a retail and wholesale level. The same applies to inedible products that are recyclable. Thus, our second theoretical contribution is that unsaleable products should be seen as a resource and an opportunity - independent of whether they are returnable, redistributable, recyclable or discardable - from which different stakeholder groups of a wholesale or retail organisation can benefit. Nevertheless, this requires the implementation of clear guidelines regarding each characteristic, in particular with respect to redistribution, and processes predetermined by the headquarters, if it is to be implemented efficiently at the store level.

Benefits of effectively managing a necessary evil in store-based wholesale and retailing: In this research we reveal the numerous reasons for products becoming unsaleable. Arguably, the common denominator of all root causes is that supply does not properly meet demand, for example, because of failures related to logistics and store operations and also due to increasing expectations on the consumer and shopper side. We thereby extend the view of, for example, Mena et al. (2014) and see the occurrence of unsaleability as an almost unavoidable, necessary evil that is inherent in the current way retailers and wholesalers operate. The cases show that, as long as there are people heavily involved in logistics processes - in particular in the ordering and replenishment processes in store - a mismatch of supply and demand is likely to occur, including both lack of availability and the unsaleability of products. The insights into the processes related to unsaleable products show that a professional and effective management of returns, redistribution, discarding and recycling can result in benefits for different stakeholder groups of retail and wholesale organisations. Our third theoretical contribution, thus, is based on the triple bottom line of sustainability (e.g. Norman and MacDonald, 2004), namely (1) the economic benefits related to recovering the value of the returned product by selling it in another store or channel and by saving the cost of waste disposal, (2) the social benefits of 
redistributing products to charities (e.g. social supermarkets and food banks) and at the same time reducing the ethical concerns of employees and (3) the ecological benefit of recycling products, in terms of the production of thermal energy and the avoidance of wastage. By extending the notions of Aiello et al. (2014) on the economic benefits of food waste, we reveal that unsaleable products are a necessary evil in the eyes of stores but nevertheless offer significant opportunities - beyond the economic ones - for retail and wholesale organisations. Setting up such processes in stores requires human resources that create costs in the short term; however, the longer-lasting benefits can contribute to an increasing pursuit of corporate social responsibility. Food waste occurs as part of the retailers' and wholesalers' activities; taking responsibility for it should be in the very interests of the retail and wholesale industry.

\subsection{Implications for practice}

Promote the bright side of unsaleability: This research provides insights into a, so far, hidden area of store operations, i.e. processes related to unsaleable products. The interviews with the store and category managers reveal a stigma related to this topic since it represents an inefficiency that, in some cases, hides behind the key performance indicator "shrinkage". Thus, the first implication for practice is to communicate the idea of unsaleability as a natural outcome of trading and to promote the opportunity to benefit from managing return, redistribution, discarding and recycling processes effectively. Such process management should then be implemented and promoted as an integral and fundamental part of a wider corporate social responsibility and sustainability programme that might be in place already. For perspective, a recent European study (Lebersorger and Schneider, 2014) reports that around 7\% of food declared unsaleable is currently being donated, while a recent study in the US reports a figure of $13.2 \%$ (BSR, 2014). This indicates the potential for corporate social responsibility in this area, as our investigation shows that even the majority of edible food is still not redistributed. 
Determine processes and enable transparency: The unofficial nature of dealing with unsaleability in stores bears the consequence that there is no sufficiently detailed measurement and information system in place. This clearly reflects the next practical implication from our research. In stores there need to be guidelines that describe how store personnel should deal with the different types of unsaleable products. More specifically, there must be simple heuristics set up to identify and distinguish between products that can be returned, redistributed, disposed of and recycled. Subsequently, clearly prescribed processes and activities must be put in place so that - the usually stretched - store personnel can efficiently handle these different kinds of unsaleable products. Obviously, some of those processes will need to include collaborations with other organisational units, for example distribution centres, other stores and channels, charities and waste collectors. Finally the different types of unsaleable products need to be considered, in retail and wholesale merchandise management and information systems, in terms of quantity and value. This will both provide a better understanding of umbrella indicators such as shrinkage, and make corporate social responsibility and sustainability efforts transparent in the management systems and promotable to the wider public. As such, the effectiveness with which stores deal with unsaleable products can become a performance as well as a sustainability indicator for store operations.

Take advantage of the knowledge and experience of store managers: This research reveals a high level of awareness amongst store managers on the issue of food waste. The high level of experience, in particular among the senior store managers, represents a large reservoir of ideas and solutions. Involving them actively in the development of new processes could contribute to better solutions and higher engagement in implementing the necessary behavioural changes among personnel at the store level, and is likely to increase the job satisfaction of employees who directly handle food waste. 


\section{Conclusions and Future Research Agenda}

The overall goal of this research was to gain an in-depth insight and better understanding of the complex instore logistics processes related to products that are declared unsaleable. For this purpose we extended the instore logistics model of Kotzab and Teller (2005) by further analysing their process "H: Disposal and Recycling". Based on our findings, we have been able to recognise the complexities related to the issue of products that are declared as unsaleable. We have found and categorised a significant number of processes, decisions and activities ranging from checking whether a product can still be sold to moving an unsaleable product to a waste collector. Depending on the residual value of a product, store managers evaluate their options in terms of, in order of preference, selling products at a marked down price, redistributing products internally, externally for social redistribution, or through other redistribution channels, or finally disposing of them. In this way, store managers show a kind of triple bottom line thinking as, on the one hand, they seek profitability but on the other they show environmental as well as social responsibility when it comes to managing the flows of unsaleable products. Our findings contribute to an extended view of instore logistics, which have so far focused only on forward flows of goods.

Our findings are transferable and applicable to other - less complex - product settings and sectors, for example apparel, homeware, furniture and consumer electrics. Based on the notions of Mena et al. (2014), we also claim that the generic nature of the phenomenon of unsaleability is similar to aspects of other supply chain stages such as the raw material production, manufacturing and warehouse distribution stages. A transfer of our findings with respect to the specificities of those parts of the supply chain is also possible. Specifically, we propose to examine in the future the following issues in regards to costs and (non-financial) benefits as well as other distribution channels and segments. 
Costs and (non-financial) benefits: Despite our significant empirical efforts, our research remains at an exploratory level. Thus, our insights give a first indication of how complex, increasingly important and relevant the topic is. The insights into the different formats clearly suggest avenues for further research in all the different processes dealing with unsaleable products. In particular the cost side, but also the returning, redistributing, discarding and recycling of products, need to be investigated in much more detail. This could entail research into the operations and viewpoints of the recipients of the unsaleable products, for example charities, waste collectors, distribution centres etc. The non-financial side of redistribution might be of particular importance, such as the benefits to wholesalers and retailers in terms of gaining a better image for corporate social responsibility and sustainability.

Other retail and wholesale sectors: The grocery retail and wholesale industry provided us with a highly dynamic and challenging environment in which to investigate the phenomenon of retail logistics and store processes related to unsaleable products. Undoubtedly, the processes investigated are very industry specific, for example due to the short shelf life, the relatively low value of the products, the high turnover and the low profit margins. Further research could look into other sectors affected by a significant share of unsaleable products as an outcome of their retail operations. This could include store-based, online or multi-channel operations in the area of apparel, consumer electrics, furniture or do-it-yourself. As outlined in our research, the focus should go beyond the return processes to entail redistribution, disposal and recycling processes as well.

Other channels: We chose store-based retail and wholesale formats since those are the most frequent formats, and very often the back-bone, of multi-channel operations. Obviously, the phenomenon of unsaleability is not unique to the formats featured in our research. Distance retail and wholesale formats in particular - for example mail order, online, home delivery, click-and-collect operations etc. - suffer similarly, and in terms of returns even more severely, from the problem of unsaleability (King et al., 2007). Future research should be encouraged to 
look into non-store-based channels and investigate the potential within that format of the effective management of all the different logistics processes related to unsaleable products.

\section{References}

Aiello, G., Enea, M. and Muriana, C. (2014), "Economic benefits from food recovery at the retail stage: An application to Italian food chains", Waste Management, Vol. 34 No. 7, pp. 1306-1316.

Autry, C.W., Daugherty, P.J. and Glenn, R.R. (2001), "The challenge of reverse logistics in catalog retailing", International Journal of Physical Distribution \& Logistics Management, Vol. 31 No. 1, pp. 26.

Avery, D.R., McKay, P.F. and Hunter, E.M. (2012), "Demography and disappearing merchandise: How older workforces influence retail shrinkage", Journal of Organizational Behavior, Vol. 33 No. 1, pp. 105-120.

Barratt, M., Choi, T.Y. and Li, M. (2011), "Qualitative case studies in operations management: Trends, research outcomes, and future research implications", Journal of Operations Management, Vol. 29 No. 4, pp. 329-342.

Berg, B.L. and Lune, H. (2012), Qualitative Research Methods for the Social Science, Pearson, Boston.

Bergmann, H. (2008), Spannungsfeld Verpackung. Erwartungen, Trends Und Konfliktfelder Aus Sicht Von Handel Und Hersteller [Conflict Area Packaging. Expectations, Trends and Conflicts from the Perspective of Retailing and Manufacturing], EHI Retail Institute, Cologne.

Bernon, M., Rossi, S. and Cullen, J. (2011), "Retail reverse logistics: A call and grounding framework for research", International Journal of Physical Distribution \& Logistics Management, Vol. 41 No. 5, pp. 484-510. 
Blackburn, J.D., Guide Jr,V. Daniel R., Souza, G.C. and Van Wassenhove, L.N. (2004), "Reverse supply chains for commercial returns", California Management Review, Vol. 46 No. 2, pp. 6-22.

Broekmeulen, R.A.C.M., van Donselaar, K.H., Fransoo, J.C. and van Woensel, T. (2004), "Excess shelf space in retail stores: An analytical model and empirical assessment", working paper, BETA Working paper, Series 109, Eindhoven University of Technology, Eindhoven.

BSR (2013), Analysis of U.S. Food Waste among Food Manufacturers, Retailers, and Wholesalers, Grocery Manufacturers Association and Food Marketing Institute, Washington.

BSR (2014), Analysis of U.S. Food Waste among Food Manufacturers, Retailers, and Restaurants, Grocery Manufacturers Association and Food Marketing Institute, Washington.

Campell, D.T. (1955), "The informant in quantitative research", American Journal of Sociology, Vol. 60 No. 4, pp. 339-342.

Chopra, S. and Meindl, P. (2012), Supply Chain Management: Strategy, Planning, and Operation, Prentice Hall, Harlow.

Corsten, D. and Gruen, T. (2003), "Desperately seeking shelf availability: An examination of the extent, the causes, and the efforts to address retail out-of-stocks", International Journal of Retail \& Distribution Management, Vol. 31 No. 12, pp. 605-617.

Creswell, J.W. (2009), Research Design. Qualitative, Quantitative and Mixed Methods Approaches, Sage, Thousand Oaks, CA.

Curseu, A., van Woensel, T., Fransoo, J., van Donselaar, K. and Broekmeulen, R. (2009), "Modelling handling operations in grocery retail stores: An empirical analysis", Journal of the Operational Research Society, Vol. 60 No. 2, pp. 200-214. 
DeHoratius, N. and Raman, A. (2007), "Store manager incentive design and retail performance: An exploratory investigation", Manufacturing \& Service Operations Management, Vol. 9 No. 4, pp. 518-534.

Deloitte (2014), Global Power of Retail 2014, Deloitte, London.

ECR Europe (2006), Shelf Ready Packaging (Retail Ready Packaging) - Addressing the Challenge: A Comprehensive Guide for a Collaborative Approach, Efficient Consumer Response (ECR) Europe, Brussels.

Ehrenthal, J.C.F. and Stölzle, W. (2013), "An examination of the causes for retail stockouts", International Journal of Physical Distribution \& Logistics Management, Vol. 43 No. 1, pp. 54-69.

European Commission (2010), Preparatory Study on Food Waste across EU 27 (Final report), European Commission in association with AEA Energy, Umwelt Bundesamt and Environment and BIO Intelligence Service, Paris.

Fisher, M. (2009), "Rocket science retailing: The 2006 Philip McCord Morse lecture", Operations Research, Vol. 57 No. 3, pp. 527-540.

Fisher, M.L. (1997), "What is the right supply chain for your product?", Harvard Business Review, Vol. 75 No. 2, pp. 105-116.

Fisher, M.L., Raman, A. and McClelland, A.S. (2000), "Rocket science retailing is almost here: Are you ready?", Harvard Business Review, Vol. 78 No. 4, pp. 115-124.

Flick, U. (2009), An Introduction to Qualitative Research, Sage, London/Thousand Oaks (CA). Ghauri, P.N. and Gronhaug, K. (2002), Research Methods in Business Studies - A Practical Guide, Prentice Hall, Essex.

Gobbi, C. (2011), "Designing the reverse supply chain: The impact of the product residual value", International Journal of Physical Distribution \& Logistics Management, Vol. 41 No. 8, pp. 768-796. 
Gooch, M., Felfel, A. \& Marenick, N. (2010), Food Waste in Canada. Opportunities to Increase the Competitiveness of Canada's Agri-Food Sector, while Simultaneously Improving the Environment, Value Chain Management Centre, Oakville.

Granzin, K.L. and Bahn, K.D. (1989), "Consumer logistics: Conceptualization, pertinent issues and a proposed program for research", Journal of the Academy of Marketing Science, Vol. 17 No. 1, pp. 91-101.

Gudehus, T. and Kotzab, H. (2012), Comprehensive Logistics, Springer, Heidelberg.

Guest, G., Bunce, A. and Johnson, L. (2006), "How many interviews are enough?: An experiment with data saturation and variability", Field Methods, Vol. 18 No. 1, pp. 59-82.

Gummesson, E. (2005), "Qualitative research in marketing", European Journal of Marketing, Vol. 39 No. 3/4, pp. 309-327.

Hall, D.,J., Huscroft, J.,R., Hazen, B.,T. and Hanna, J.,B. (2013), "Reverse logistics goals, metrics, and challenges: Perspectives from industry", International Journal of Physical Distribution \& Logistics Management, Vol. 43 No. 9, pp. 768-785.

Holweg, C. and Lienbacher, E. (2011), "Social supermarkets: A new challenge in supply chain management and sustainability", Supply Chain Forum: An International Journal, Vol. 11 No. 4, pp. 50-59.

Howell, S.D. and Proudlove, N.C. (2007), "A statistical investigation of inventory shrinkage in a large retail chain", International Review of Retail, Distribution \& Consumer Research, Vol. 17 No. 2, pp. 101-120.

Jones, T. 2004, "Using contemporary archaeology and applied anthropology to understand food loss in the American food system", available at: http://www.communitycompost.org/info/usafood.pdf, (accessed 09 April 2015)

Katajajuuri, J., Silvennoinen, K., Hartikainen, H., Heikkilä, L. and Reinikainen, A. (2014), "Food waste in the Finnish food chain", Journal of Cleaner Production, Vol. 73, pp. 322329. 
King, T., Dennis, C. and McHendry, J. (2007), "The management of deshopping and its effects on service: A mass market case study", International Journal of Retail \& Distribution Management, Vol. 35 No. 9, pp. 720-733.

Kotzab, H. and Teller, C. (2005), "Development and empirical test of a grocery retail instore logistics model", British Food Journal, Vol. 107 No. 8, pp. 594-605.

Krikke, H., le Blan, L. and van de Velde, S. (2004), "Product modularity and the design of closed-loop supply chains", California Management Review, Vol. 46 No. 2, pp. 23-39.

Krippendorff, K.H. (2004), Content Analysis: An Introduction to its Methodology, Sage, Thousand Oaks, CA.

Lebersorger, S. and Schneider, F. (2014), "Food loss rates at the food retail, influencing factors and reasons as a basis for waste prevention measures", Waste Management, Vol. 34 No. 11, pp. 1911-1919.

Mayring, P. (2000), "Qualitative content analysis", Forum: Qualitative Social Research, Vol. 1 No. 2, Art 20.

Mena, C., Terry, L.A., Williams, A. and Ellram, L. (2014), "Causes of waste across multi-tier supply networks: Cases in the UK food sector", International Journal of Production Economics, Vol. 152, pp. 144-158.

Norman, W. and MacDonald, C. (2004), "Getting to the bottom of "triple bottom line"", Business Ethics Quarterly, Vol. 14 No. 2, pp. 243-262.

Papargyropoulou, E., Lozano, R., K. Steinberger, J., Wright, N. and Ujang, Z.b. (2014), "The food waste hierarchy as a framework for the management of food surplus and food waste", Journal of Cleaner Production, Vol. 76 No. 0, pp. 106-115.

Raman, A., DeHoratius, N. and Ton, Z. (2001), "Execution: The missing link in retail operations", California Management Review, Vol. 43 No. 3, pp. 136-152. 
Reiner, G., Teller, C. and Kotzab, H. (2013), "Analyzing the efficient execution of in-store logistics processes in grocery retailing - the case of dairy products", Production and Operations Management, Vol. 22 No. 4, pp. 924-939.

Rekik, Y. and Sahin, E. (2012), "Exploring inventory systems sensitive to shrinkage - analysis of a periodic review inventory under a service level constraint", International Journal of Production Research, Vol. 50 No. 13, pp. 3529-3546.

Reutterer, T. and Teller, C. (2009), "Store format choice and shopping trip types", International Journal of Retail \& Distribution Management, Vol. 37 No. 8, pp. 695-710.

Schneider, F. and Wassermann, G. (2004), Sozialer Wertstofftransfer im Einzelhandel [Social transfer of products in retail], Initiative`Abfallvermeidung in Wien`, Vienna.

Sinkovics, R.R., Penz, E. and Ghauri, P.N. (2005), "Analysing textual data in international marketing research", Qualitative Market Research: An International Journal, Vol. 8 No. 1, pp. 9-38.

Stenmarck, Å, Hanssen, O.J. \& Werge, M. (2011), Initiatives on Prevention of Food Waste in the Retail and Wholesale Trades, Nordic Council of Ministers, Copenhagen.

Stuart, I., McCutcheon, D., Handfield, R., McLachlin, R. and Samson, D. (2002), "Effective case research in operations management: A process perspective", Journal of Operations Management, Vol. 20 No. 5, pp. 419-433.

Teller, C., Kotzab, H. and Grant, D.B. (2011), "The relevance of shopper logistics for consumers of store-based retail formats", Journal of Retailing and Consumer Services, Vol. doi:10.1016/j.jretconser.2011.09.001.

Tibben-Lembke, R.S. and Rogers, D.S. (2002), "Differences between forward and reverse logistics in a retail environment", Supply Chain Management, Vol. 7 No. 5, pp. 271-282. van Donselaar, K.H., Gaur, V., van Woensel, T., Broekmeulen, R.A.C.M. and Fransoo, J.C. (2010), "Ordering behavior in retail stores and implications for automated replenishment", Management Science, Vol. 56 No. 5, pp. 766-784. 
van Donselaar, K., van Woensel, T., Broekmeulen, R. and Fransoo, J. (2006), "Inventory control of perishables in supermarkets", International Journal of Production Economics, Vol. 104 No. 2, pp. 462-472.

van Zelst, S., van Donselaar, K., van Woensel, T., Broekmeulen, R. and Fransoo, J. (2009), "Logistics drivers for shelf stacking in grocery retail stores: Potential for efficiency improvement", International Journal of Production Economics, Vol. 121 No. 2, pp. 620632.

Weber, R.P. (1990), Basic Content Analysis, Sage, Newbury Park. 